Article

\title{
Verification of Non-thermal Effects of 0.3-0.6 THz-Waves on Human Cultured Cells
}

\author{
Noriko Yaekashiwa ${ }^{1, *(D)}$, Hisa Yoshida ${ }^{1}$, Sato Otsuki ${ }^{1}$, Shin'ichiro Hayashi ${ }^{1,2}{ }^{10}$ and \\ Kodo Kawase ${ }^{1,3}$ \\ 1 RIKEN, Center for Advanced Photonics, Sendai 980-0845, Japan; hisa.yoshida@riken.jp (H.Y.); \\ Otsuki.Sato@technopro.com (S.O.); hayashi@nict.go.jp (S.H.); kawase@nuee.nagoya-u.ac.jp (K.K.) \\ 2 Terahertz technology research Center, National Institute of Information and Communications Technology, \\ Koganei 184-8795, Japan \\ 3 Graduate School of Engineering, Nagoya University, Nagoya 464-8603, Japan \\ * Correspondence: yaekashiwa@riken.jp; Tel.: +81-22-228-2124
}

Received: 30 January 2019; Accepted: 21 March 2019; Published: 25 March 2019

check for updates

\begin{abstract}
Recent progress has been made in the development of terahertz (THz) waves for practical applications. Few studies that have assessed the biological effects of $\mathrm{THz}$ waves have been reported, and the data currently available regarding the safety of $\mathrm{THz}$ waves is inadequate. In this study, the effect of $\mathrm{THz}$ wave exposure on two cultured cells was assessed using a widely tunable $\mathrm{THz}$ source with a $0.3-0.6 \mathrm{THz}$ frequency range, which can be used and increased in one $\mathrm{GHz}$ increments. The THz waves applied to the cultured cells were weak enough such that any thermal effects could be disregarded. The influence of $\mathrm{THz}$ wave exposure on both the proliferative and metabolic activities of these cells was investigated, as well as the extent of the thermal stress placed on the cells. In this work, no measurable effect on the proliferative or metabolic activities of either cell type was observed following the exposure to $\mathrm{THz}$ waves. No differences in the quantity of cDNA related to heat shock protein 70 was detected in either the sham or exposure group. As such, no differences in cellular activity between cells exposed to $\mathrm{THz}$ waves and those not exposed were observed.
\end{abstract}

Keywords: Terahertz (THz); non-thermal effect; long-term exposure; 1-GHz frequency steps; widely tunable source; human cultured cells

\section{Introduction}

The number of devices that use electromagnetic waves has increased in recent years, with rapid progress being made in the development of applications for waves such as in high-speed communication and security scanning technologies in the millimeter and terahertz (THz) frequency ranges [1], including wireless data transmission at 24 and $40 \mathrm{Gbit} / \mathrm{s}$ at $300 \mathrm{GHz}$ using a Uni-Travelling-Carrier Photodiode (UTC-PD) [2,3]. As THz technology advances, studies of the biological effects of exposure to $\mathrm{THz}$ waves are required. Despite this, to the best of our knowledge, no adequate assessment of the biological effects of electromagnetic waves at these frequencies has been made [4]. Wilmink et al. [5] reviewed that irradiation with $\mathrm{THz}$ waves at high intensity can generate heat and damage cells.

According to recent research trends published by the Scientific Committee on Emerging and Newly Identified Health Risks (SCENIHR) of the European Commission [6], there have been few studies to date that investigate the biological effects of the THz frequency range $(0.1-1.0 \mathrm{THz})$. The SCENIHR report recommended further research focusing on the impact of THz waves on the skin (low-intensity long-term exposure) and eyes (high-intensity short-term exposure). In recent years, increasing research attention has been focused on the frequency range near $0.1 \mathrm{THz}$ 
$\left(0.031-5 \mathrm{~mW} / \mathrm{cm}^{2}\right)$ [7-13], which studied genomic instability and damage, genotoxicity, morphological changes, enzyme activity, etc. In addition, a number of studies have focused on the frequency range near $2 \mathrm{THz}\left(0.03 \mathrm{~mW} / \mathrm{cm}^{2}-1.4 \mathrm{~W} / \mathrm{cm}^{2}\right)$ [14-19], which studied gene expression, DNA damages, genotoxicity, inflammatory responses and stress systems etc. Research that examines the biological effects of exposure to the $0.2-2.0 \mathrm{THz}$ frequency range is still lacking.

Fröhlich hypothesized that the frequency at which resonance oscillation occurs in the cell membrane (phospholipid bilayer) exists in the $\mathrm{THz}$ band (approximately $0.1-1 \mathrm{THz}$ ) [20], suggesting that the $\mathrm{THz}$ wave band may have non-thermal effects. Several reports published thus far have claimed to have verified this hypothesis for the frequency band below $0.1 \mathrm{THz}$ [21-23]. However, this hypothesis has not been entirely verified by these studies, as the frequencies investigated were lower than expected, and the tuning range of the millimeter wave sources used were insufficient. Recent advancements in technology have allowed the development of millimeter-wave/THz-wave sources that are capable of variable frequencies (widely tunable) and are also tunable by $1 \mathrm{GHz}$ steps within a wide range. One wave source with this capability is the UTC-PD. Using the UTC-PD, we aimed to investigate the potential non-thermal effects of long-term exposure to weak radiation, thereby allowing any thermal effects (frequency range: $0.3-0.6 \mathrm{THz}$, intensity: $<4.5 \mu \mathrm{W} / \mathrm{cm}^{2}$ ) on cultured cells to be ignored.

We proposed a novel method for observing the morphology of cells irradiated with $\mathrm{THz}$ waves. Many studies of the biological effects of $\mathrm{THz}$ irradiation have exposed samples through the bottoms of dishes because of the high water absorptance in the THz region [24-26]. However, this method cannot be used with an inverted microscope, as high-magnification objective lenses block THz irradiation. An inverted microscope is useful for observing adherent and suspended cells and various microbes cultured in dishes. We devised a simple method for irradiating the dishes with $\mathrm{THz}$ waves from above.

\section{Materials and Methods}

\subsection{THz Wave Source}

A UTC-PD (NTT Electronics Inc., Yokohama, Japan) was used as the millimeter-wave/THz-wave source. This wave source generates tunable continuous waves, from $10 \mathrm{GHz}$ to $2 \mathrm{THz}$, by photomixing two wavelength-tunable laser diodes of approximately $1.55 \mu \mathrm{m}$ on the photodiode [27]. In this study, the wave source was placed in the incubator (positioned approximately $100 \mathrm{~mm}$ below the culture well) and the beam divergence angle was adjusted using a silicon lens [28] to ensure that the entire bottom of the well was irradiated (Figure 1a,b). Figure 2 shows the frequency dependence of the irradiation intensity inside the culture well (a) and 96-well plate (b). The frequency range of the irradiated $\mathrm{THz}$ waves was $0.3-0.6 \mathrm{THz}$. In the case of the culture well, the irradiated $\mathrm{THz}$ wave covered the well through an aluminum waveguide, with an intensity less than $1 \mu \mathrm{W} / \mathrm{cm}^{2}$, including both coupling and propagating loss by the waveguide and an absorption loss by the bottom of cell. In the case of the 96-well plate, the irradiated $\mathrm{THz}$ wave covered all of the 96 wells through free space, with the intensity approximately $0.1 \mu \mathrm{W} / \mathrm{cm}^{2}$, including absorption loss by the bottom of the well. 


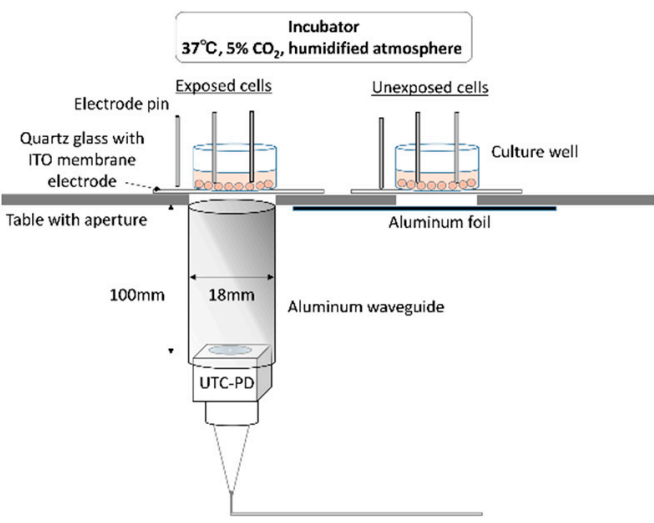

(a)

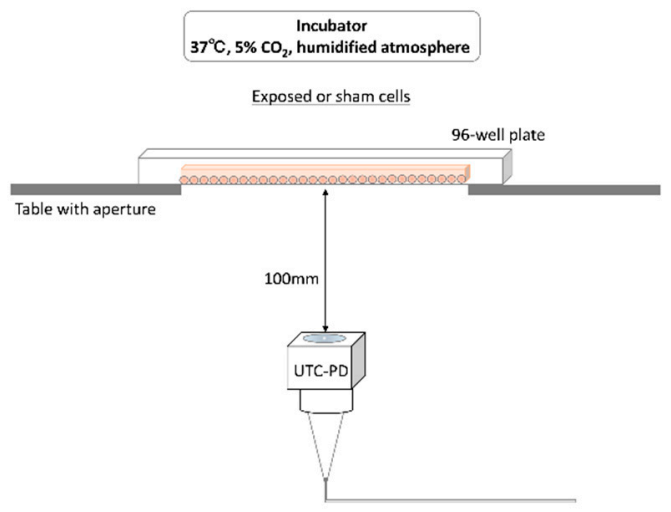

(b)

Figure 1. Scheme of the exposure set-up showing the terahertz $(\mathrm{THz})$ wave source in the incubator chamber for measuring cell proliferation (a) and cell viability (b).

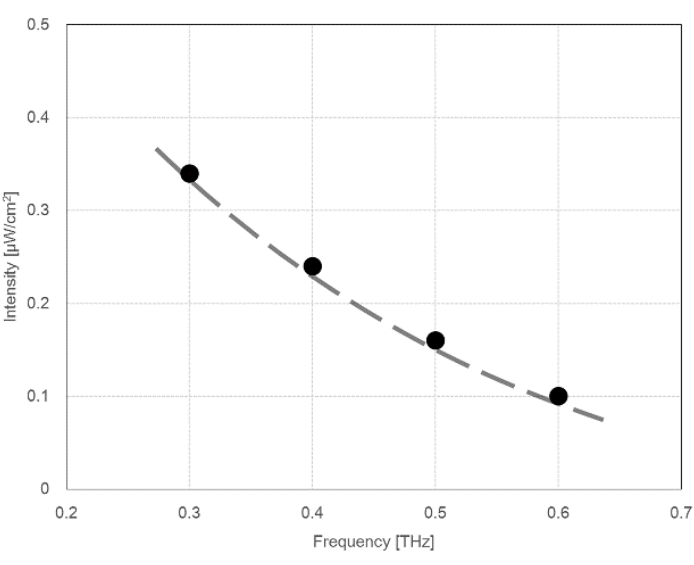

(a)

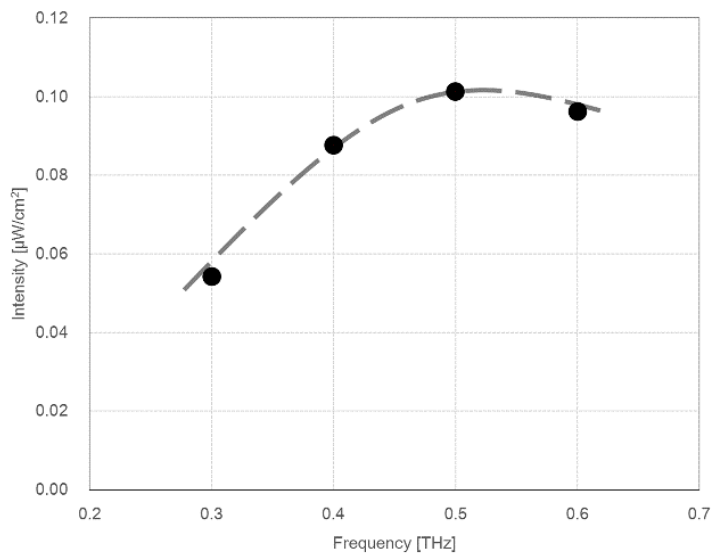

(b)

Figure 2. The frequency dependence on the irradiation intensity inside the culture well (a) and 96-well plate (b). (a) The irradiated THz wave covered the well through an aluminum waveguide. The intensity was less than $1 \mu \mathrm{W} / \mathrm{cm}^{2}$ including coupling and propagating loss by the waveguide and an absorption loss by the bottom of the cell. (b) The irradiated THz wave covered all of the 96 -well plate through free space with the intensity approximately $0.1 \mu \mathrm{W} / \mathrm{cm}^{2}$, including an absorption loss by the bottom of the well.

The absolute power and beam profile of the $\mathrm{THz}$ waves were measured using a pre-calibrated pyroelectric detector (THz 20; Sensor und Lasertechnik, Wildau, Germany) and an InSb Hot Electron Bolometer (QFI/X; QMC Instruments Ltd., Cardiff, UK), respectively. Temperature shifts inside the incubator caused by the self-heating of the UTC-PD were observed to be less than $0.3^{\circ} \mathrm{C}$.

We devised a simple method for irradiating the dishes with $\mathrm{THz}$ waves from above to observe cell morphology. To irradiate from the top of the dish, the irradiation system was constructed on the inverted microscope stage (Figure 3). The irradiation light from the UTC-PD was converged in a lens (Tsurupica; PAX Co., Sendai, Japan). The irradiation intensity was estimated from the output of the light source and the beam diameter on the dish to be $4.1 \sim 5 \mu \mathrm{W} / \mathrm{cm}^{2}$ at $0.3-0.6 \mathrm{THz}$. 


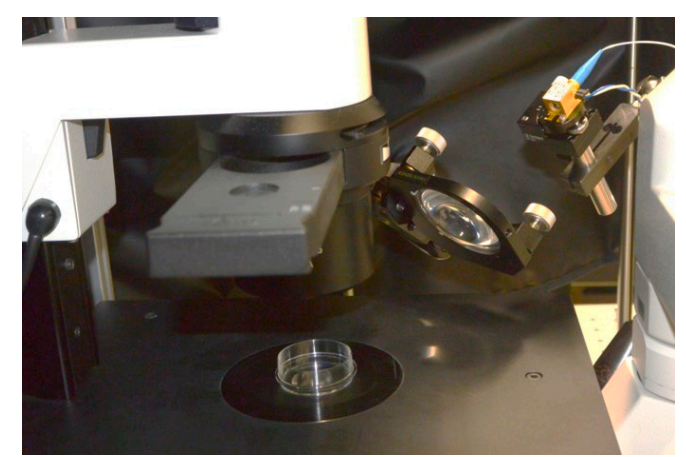

Figure 3. Uni-Travelling-Carrier Photodiode (UTC-PD) optical system on the inverted microscope.

\subsection{Cells Used for the $\mathrm{THz}$ Wave Exposure}

Two cell lines were cultured for use in this study. Normal human skin fibroblast (NB1RGB) and human corneal epithelial (HCE-T) cells lines [29] were both obtained from RIKEN BioResource Research Center, Japan. To culture NB1RGB cells, 10\% fetal bovine serum (USDA Tested FBS; GE Healthcare UK Ltd., Little Chalfont, England) was added to MEM $1 \times$ ALPHA plus GlutaMax (Life Technologies Corporation, Carlsbad, CA, USA). To culture HCE-T cells, 5\% FBS, $5 \mu \mathrm{g} / \mathrm{mL}$ insulin, $10 \mathrm{ng} / \mathrm{mL}$ hEGF, and 0.5\% dimethylsulfoxide (DMSO) were added to DMEM:HamF12 (1:1) (FUJIFILM Wako Pure Chemical Corporation, Osaka, Japan). Incubation was carried out at $37^{\circ} \mathrm{C}$ in a saturated steam environment and a $5 \% \mathrm{CO}_{2}$ atmosphere.

\subsection{Cell Proliferation}

An alternating current impedance measurement method (BM2401; HIOKI E.E. CORPORATION, Ueda, Japan) was used for cell proliferation. Figure 1a shows a scheme of the exposure set-up for cell proliferation. An ITO membrane electrode was affixed to the bottom (area: $0.785 \mathrm{~cm}^{2}$ ) of the culture well. In this method of measuring cell proliferation, the impedance current flow between the ITO electrode membrane and electrode pin was recorded. The impedance value changes during cell growth on the ITO membrane. If the cells adhered to the ITO membrane electrode proliferate, the flow of the electrical current is disturbed, and the impedance value would increase. The reactance ratio was calculated based on this value, and the cellular growth curve was derived from this ratio. Cell proliferation was indirectly measured using the method described above. The impedance value was measured at a frequency of $100 \mathrm{kHz}$ every $5 \mathrm{~min}$ over a $94 \mathrm{~h}$ period. As a positive control, $20 \%$ of DMSO was added to cells instead of $\mathrm{THz}$ wave irradiation.

The emitter of the UTC-PD was placed in an aluminum light pipe positioned $100 \mathrm{~mm}$ below the bottom of the culture well that contained the exposed cells. The bottom of the well containing the unexposed cells was covered with an aluminum foil impermeable to $\mathrm{THz}$ waves to prevent exposure. The bottom of the culture wells had a thickness of $0.7 \mathrm{~mm}$ and approximately $10 \% \mathrm{THz}$ wave permeability. Twelve thousand cells were seeded per well and cultured normally for $26 \mathrm{~h}$. The exposed cells were then continuously exposed to $\mathrm{THz}$ waves, starting at a frequency of $0.3 \mathrm{THz}$ and increasing to $0.6 \mathrm{THz}$ in 1-GHz steps every $18 \mathrm{~min}$ and $34 \mathrm{~s}$ over a $94 \mathrm{~h}$ period. Following exposure, the cells were observed under a microscope (DM IL LED; Leica Microsystems, Wetzlar, Germany).

\subsection{Cell Viability}

We investigated the viability of cells exposed to $\mathrm{THz}$ waves during cell proliferation. A 96-well plate (THz wave permeability of $90 \%$; Corning, Corning, NY, USA) was used for the cell culture. To ensure consistency in the measurement between the exposed and sham cells, two incubators of the same model were used, one for each group (Figure 1b).

Cell viability for each cell group was determined using the MTT assay [30]. Four thousand cells were seeded in a single well of a 96-well plate and cultured for $2 \mathrm{~h}$, until the cells adhered to the 
surface at the bottom of the well. The exposure group cells were then continuously exposed to $\mathrm{THz}$ waves, starting at a frequency of $0.3 \mathrm{THz}$, increasing to $0.6 \mathrm{THz}$ with 1-GHz steps every $13 \mathrm{~min}$ and $47 \mathrm{~s}$ over a $70 \mathrm{~h}$ period. The colorimetric assay reagent CellTiter 96®AQueous One Solution Cell Proliferation Assay (Promega Corporation, Madison, WI, USA) [31] was added directly to the cells $72 \mathrm{~h}$ after seeding. The cells were then cultured for $3 \mathrm{~h}$ without any further exposure. Absorbance at $490 \mathrm{~nm}$ was measured using a microplate reader (iMark microplate reader; Bio-Rad Laboratories, Inc., Hercules, CA, USA). The positive control cells were cultured at temperatures greater than $43^{\circ} \mathrm{C}$ for $70 \mathrm{~h}$, and their viability was taken to be the normal culture environment for any comparisons.

Experiments were also conducted that involved changing the timing of exposure, following the same procedure. Cells were cultured for $72 \mathrm{~h}$ without exposure to $\mathrm{THz}$ waves. After culturing, reagents were added directly to the cells and cultured for another $3 \mathrm{~h}$. Cells were then exposed to THz waves during this $3 \mathrm{~h}$ incubation time. The frequency of the exposure stimulus was increased by increments of $1-\mathrm{GHz}$ every $25 \mathrm{~s}$ (from $0.3 \mathrm{THz}$ to a maximum of $0.6 \mathrm{THz}$ ). The absorbance at $490 \mathrm{~nm}$ was then measured. As a positive control, cells were exposed to DMSO, known to be highly cytotoxic at high concentrations, for $3 \mathrm{~h}$. DMSO was directly added to the cells after the absorbance was measurement was taken.

\subsection{Morphological Observations of Human Corneal Cells (HCE-T) Exposed}

We monitored the morphological changes of human cornea cells (HCE-T) exposed to 0.3, 0.4, 0.5, and $0.6 \mathrm{THz}$ from a variable broadband $\mathrm{THz}$ source and an irradiation time of $10 \mathrm{~min}$. We showed experimental results of morphology in HCE-T cells with sensitive to change. HCE-T were cultured for 5 days and the confluent cells were stained with CellBrite Green cytoplasmic membrane dye (Biotium, Inc., Fremont, CA, USA), a fat-soluble carbocyanine dye that emits strong fluorescence when incorporated in a lipid bilayer membrane. The growth medium was aspirated. Then, $2.5 \mu \mathrm{L}$ cell-labeling solution was added to $1 \mathrm{~mL}$ growth medium and mixed well, and $200 \mu \mathrm{L}$ was added to the culture medium. The cells were incubated at $37^{\circ} \mathrm{C}$ for $30 \mathrm{~min}$. The staining medium was aspirated, and the cells washed three times. For each wash cycle, the cells were covered with warmed fresh growth medium and incubated at $37^{\circ} \mathrm{C}$ for $5 \mathrm{~min}$. After washing, warmed growth medium $20 \mu \mathrm{L}$ was added to the cells, and a cell disk (LF1:MS-92132 Sumitomo Bakelite, Tokyo, Japan) was put on the cells. The total estimated thickness of the culture medium, cells, and cell desk was about $75 \mu \mathrm{m}$. Based on the water absorption coefficients in the THz region $\left(\alpha=131,146,160\right.$, and $176 \mathrm{~cm}^{-1}$ at $0.3,0.4$, 0.5 , and $0.6 \mathrm{THz}$, respectively) and the transmittance of the cell disk $(88,86,83$, and $84 \%$ at $0.3,0.4$, 0.5 , and $0.6 \mathrm{THz}$, respectively), the transmittance was $20-30 \%$, and the $\mathrm{THz}$ wave intensity at the cells was approximately 1.0 1.4 $\mathrm{HW} / \mathrm{cm}^{2}$. An inverted microscope (Leica, DMIL LED) and a fluorescence source (Leica EL6000) were used for cell observation before and after irradiation. Film-bottom dishes (FD10300 Matsunami Glass, Kishiwada, Japan) with a thin central bottom area for clear viewing were used for cell culture. To compare cell shapes, two positive controls were prepared: heat treatment at $43^{\circ} \mathrm{C}$ for $10 \mathrm{~min}$ and immersion in DMSO for $10 \mathrm{~min}$.

\subsection{Assessment of the Level of Heat Shock Protein 70 mRNA Expression}

mRNA expression levels of heat shock protein 70 (HSP70), which is expressed in cells in response to heat stress, were assessed. Total mRNA was extracted from cells using the RNeasy Plus Mini Kit (QIAGEN, Hilden, Germany). HSP70 cDNA was then subsequently obtained using reverse transcription-polymerase chain reaction (RT-PCR). The primers used in this study are listed in Table 1 [32,33]. The PrimeScript One Step RT-PCR Kit Ver. 2 (Takara Bio Inc., Kusatsu, Japan) was used for RT-PCR. Amplification was performed using a thermal cycler as follows: $50{ }^{\circ} \mathrm{C}$ for $30 \mathrm{~min}, 94{ }^{\circ} \mathrm{C}$ for $2 \mathrm{~min}$, followed by 30 cycles of $94^{\circ} \mathrm{C}$ for $30 \mathrm{~s}, 60^{\circ} \mathrm{C}$ for $30 \mathrm{~s}$, and $72{ }^{\circ} \mathrm{C}$ for $60 \mathrm{~s}$. The final cycle was maintained at $4{ }^{\circ} \mathrm{C}$. $\beta$-actin was used as an internal standard. Synthesized PCR products were stained with Midori Green Direct (NIPPON Genetics Co., Ltd., Tokyo, Japan) and electrophoresed in a 2\% agarose gel at $100 \mathrm{~V}$ for $28 \mathrm{~min}$. 
Table 1. List of primers used for RT-PCR.

\begin{tabular}{|c|c|c|c|c|}
\hline Gene & & Sequence & $\begin{array}{c}\text { Amplified } \\
\text { Length (bps) }\end{array}$ & $\begin{array}{l}\text { Sequence } \\
\text { Reference }\end{array}$ \\
\hline HSP70 & $\begin{array}{l}\text { sense: } \\
\text { antisense: }\end{array}$ & $\begin{array}{l}5^{\prime}-\text { TTCCGTTTCCAGCCCCCAATC -3' } \\
5^{\prime} \text { - CGTTGAGCCCCGCGATGACA - -3' }\end{array}$ & 558 & Wang. 1999 \\
\hline$\beta$-actin & $\begin{array}{l}\text { sense: } \\
\text { antisense: }\end{array}$ & $\begin{array}{l}5^{\prime}-\text { CCGCGAGAAGATGACCCAGAT -3' } \\
5^{\prime}-\text { TTCTCCTTAATGTCACGCACGAT -3' }\end{array}$ & 299 & Lixia. 2006 \\
\hline
\end{tabular}

\subsection{Statistical Analysis Method}

Cell proliferation and cell viability experiments were performed in triplicate. Cell growth curves were derived by averaging $3-4$ sets of measurement data at each frequency. Cell viability was calculated as the mean value \pm standard deviation (SD). Cellular activity and cell viability were calculated based on radiation absorbance exhibited, with the absorbance by unexposed or sham cells taken to be $100 \%$ and the absorbance by exposed cells calculated as (absorbance by exposed cells/absorbance by unexposed or sham cells) $\times 100 \%$. Exposed, unexposed, or sham cells were then compared with respect to each data set and subjected to a significant difference test (risk ratio: 95\%), comprising the $t$-test.

\section{Results}

\subsection{Cell Proliferation}

Figure 4 presents the cell growth curve based on the AC impedance measurement method for each cell line. We observed that cells exposed to $0.3-0.6 \mathrm{THz}$ waves for $94 \mathrm{~h}$ exhibited no difference in terms of proliferation compared to cells not exposed to these $\mathrm{THz}$ frequencies (average of three independent experiments [SD: 0.00-0.16]). The reactance ratios did not show a significant difference between the exposed and unexposed cells; $p=0.51$ (NB1RGB) and 0.48 (HCE-T), respectively. Comparing the reactance ratios at each irradiation frequency, no effect on cell proliferation attributable to a specific frequency could be identified. Cell growth was observed for both exposed and unexposed cells, however, those treated with DMSO did not grow. No differences between exposed and unexposed cells were identified (Figure 5).

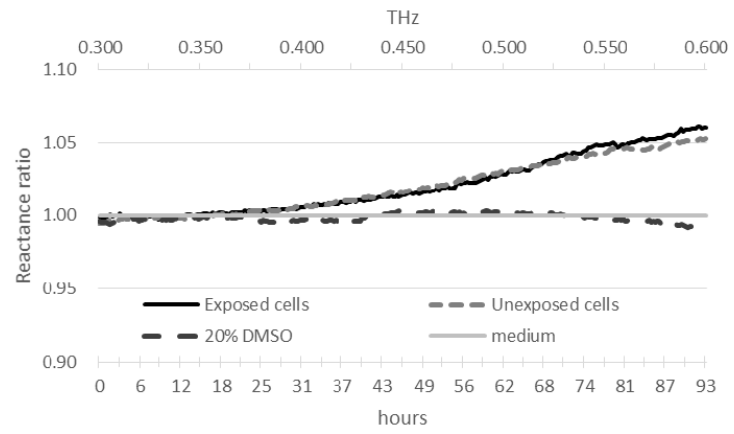

(a)

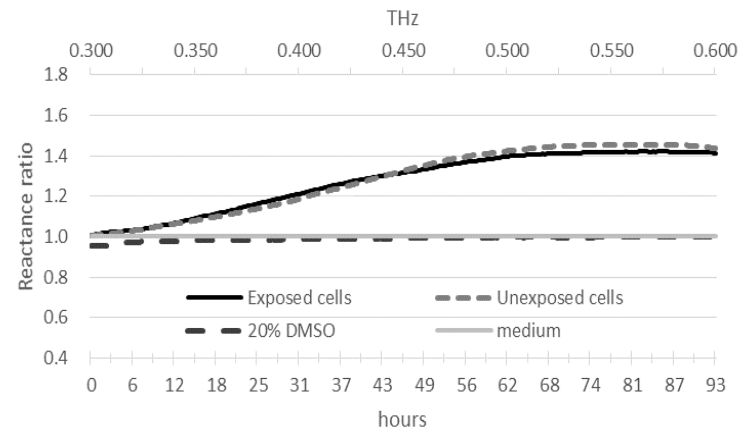

(b)

Figure 4. Growth curves of cells that have been exposed to $0.3-0.6 \mathrm{THz}$ waves. The solid line represents exposed cells, the broken line represents unexposed cells, the dash line represents adding $20 \%$ of DMSO and the gray line represents the culture medium without cells. Cells were exposed to waves from $0.3 \mathrm{THz}$ to $0.6 \mathrm{THz}$, increasing at a rate of $1.0 \mathrm{GHz}$ every $18 \mathrm{~min}$ and $34 \mathrm{~s}$, over a total of $94 \mathrm{~h}$. (a) NB1RGB cell proliferation curve. (b) HCE-T cell proliferation curve. Data were independently collected three times and the data measured at each frequency was averaged. 


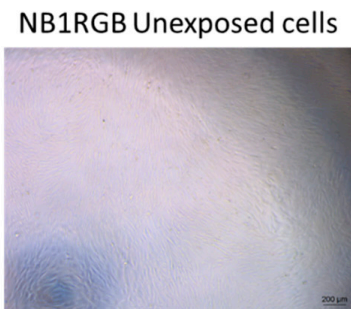

HCE-T Unexposed cells

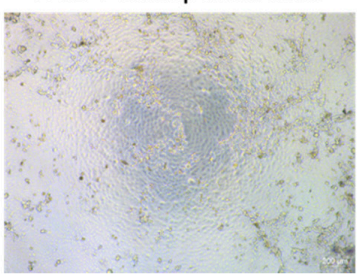

NB1RGB Exposed cells

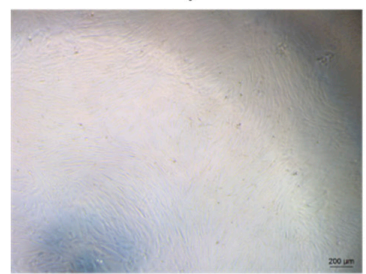

HCE-T Exposed cells

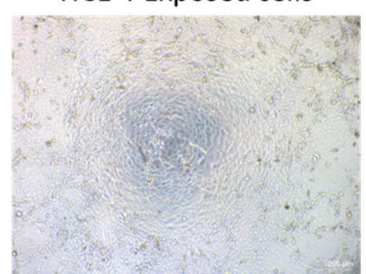

NB1RGB with DMSO

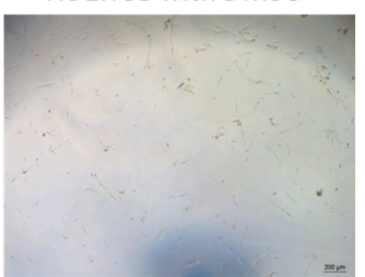

HCE-T with DMSO

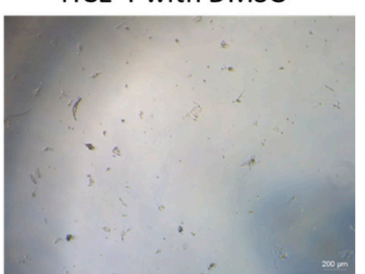

Figure 5. Cells following exposure to $0.3-0.6 \mathrm{THz}$ waves for $94 \mathrm{~h}(\mathrm{x} 5)$.

\subsection{Cell Viability}

Figure 6 shows cell viability following exposure to $0.3-0.6 \mathrm{THz}$ waves during cell proliferation and sham cells. In addition, cells cultured for $70 \mathrm{~h}$ at $43^{\circ} \mathrm{C}$ (positive control) exhibited a significant decrease in viability (NB1RGB: $88 \%$ decrease; HCE-T: 98\% decrease) compared with sham cells $(p<0.01)$. By contrast, the cells exposed to $\mathrm{THz}$ and the sham cells demonstrated no observable difference in cell viability.

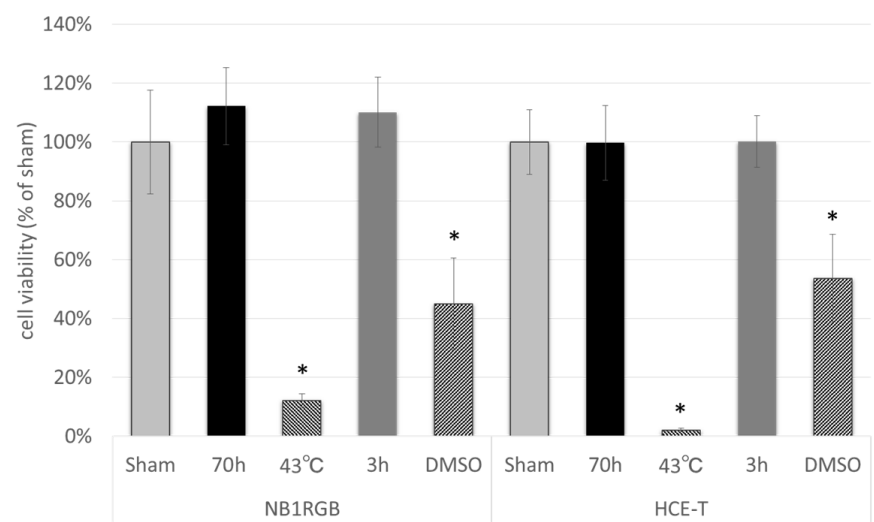

Figure 6. Viability of cells exposed to frequencies between 0.3 and $0.6 \mathrm{THz}$. Viability of NB1RGB and HCE-T cells after $70 \mathrm{~h}$ or $3 \mathrm{~h}$ of exposure following the MTT assay. Viability of NB1RGB and HCE-T cells subjected to different exposure conditions sham cells incubated at $43^{\circ} \mathrm{C}$ for $70 \mathrm{~h}$ and cells cultured with $0.7 \mathrm{M}$ DMSO for $3 \mathrm{~h}$ as a positive control. The data display the mean of three independent experiments \pm standard deviation. ${ }^{*} p<0.01$ for $\mathrm{t}$-test comparing the control and heating effects or with DMSO.

The viability of cells exposed to $0.3-0.6 \mathrm{THz}$ waves for $3 \mathrm{~h}$ after proliferation did not differ from that of the sham cells of both cell types. DMSO, which is cytotoxic at high concentrations, was added to the positive control cells. After $3 \mathrm{~h}$ of incubation with DMSO, cell viability significantly decreased: by $55 \%$ and $46 \%$ in the NB1RGB and HCE-T cell groups, respectively $(p<0.01$; Figure 6$)$.

\subsection{Morphological Observations of Human Corneal Cells (HCE-T) Exposed}

Fluorescence microscope and phase-contrast microscope observations showed that the cell shape and cell membrane did not change on irradiation at $0.3,0.4,0.5$, and $0.6 \mathrm{THz}$ (Figure 7). No differences due to the $\mathrm{THz}$ frequency $(0.3-0.6 \mathrm{THz})$ were seen. Cells were obviously damaged by heating. The cell 
shapes changed, and the cells peeled off the dish bottoms (Figure 8a). With the addition of 30\% DMSO, cells were damaged, and their nuclei were contracted (Figure $8 b$ ).

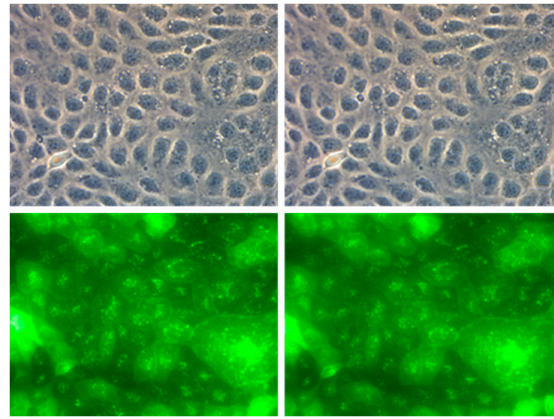

(a)

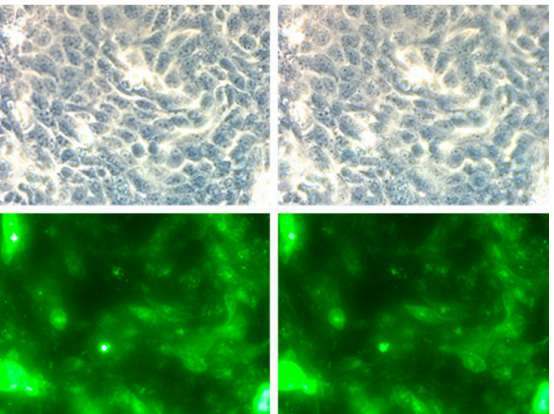

(b)
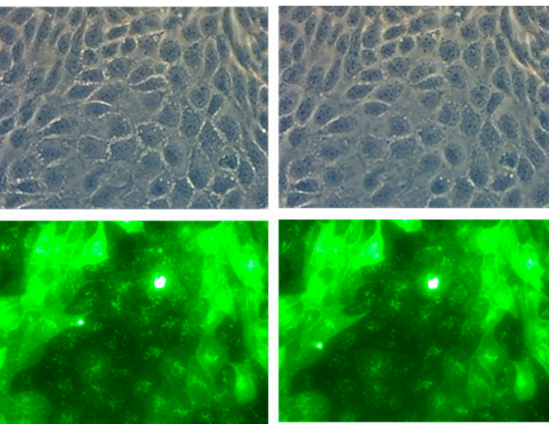

(d)

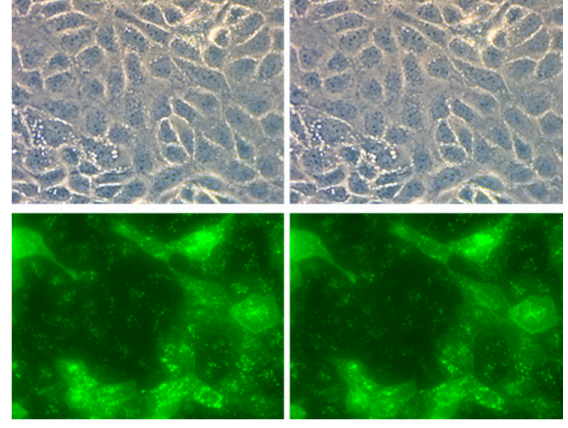

(c)

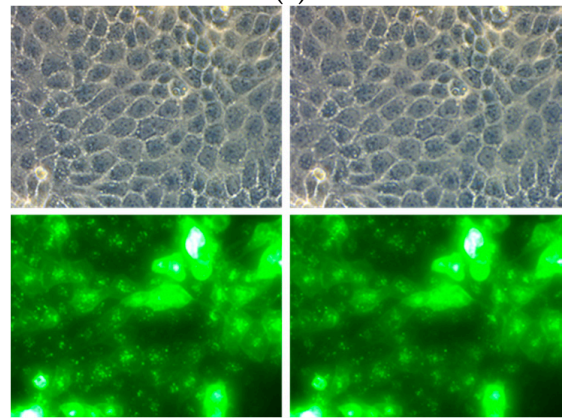

(e)

Figure 7. Change in cell shape the before (left) and after (right) $(\times 63)$, phase contrast (top) and fluorescence (bottom) micrographs. (a) control treatment. (b-e) $0.3,0.4,0.5,0.6 \mathrm{THz}$ irradiation respectively.

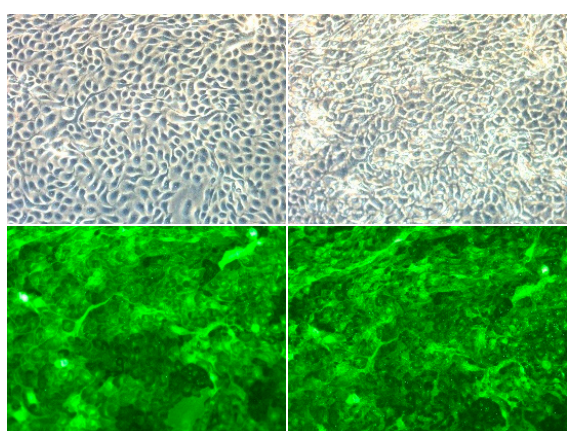

(a)

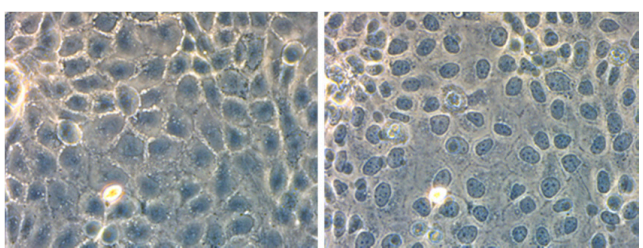

(b)

Figure 8. Change in cell shape $(\mathbf{a})$ with heat treatment $(\times 20)$ and $(\mathbf{b})$ with dimethylsulfoxide (DMSO) treatment $(\times 63)$ before (left) and after (right), phase contrast (top) and fluorescence (bottom) micrographs. 


\subsection{Detection of HSP70 mRNA Expression}

We assessed the level of HSP70 mRNA expression as a result of exposure to $0.3-0.6 \mathrm{THz}$ waves using RT-PCR. No differences in the level of HSP70 mRNA expression between the exposed and sham cells were observed (Figure 9). Similarly, no differences were observed with respect to $\beta$-actin expression levels as a result of exposure.

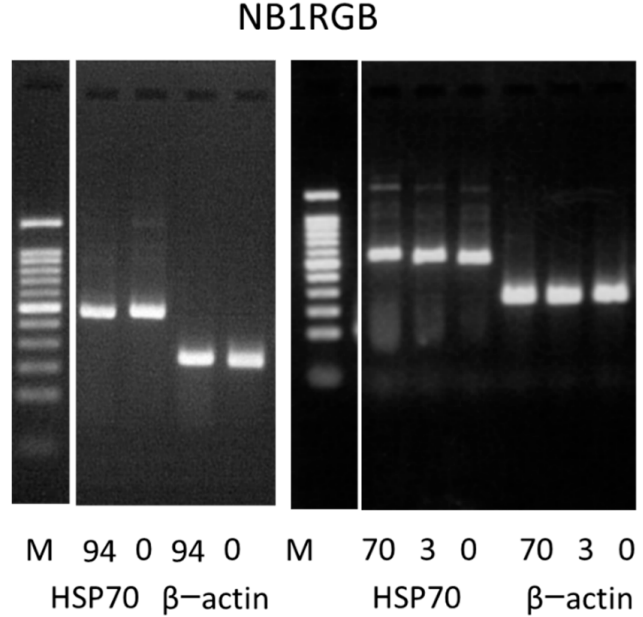

(a)

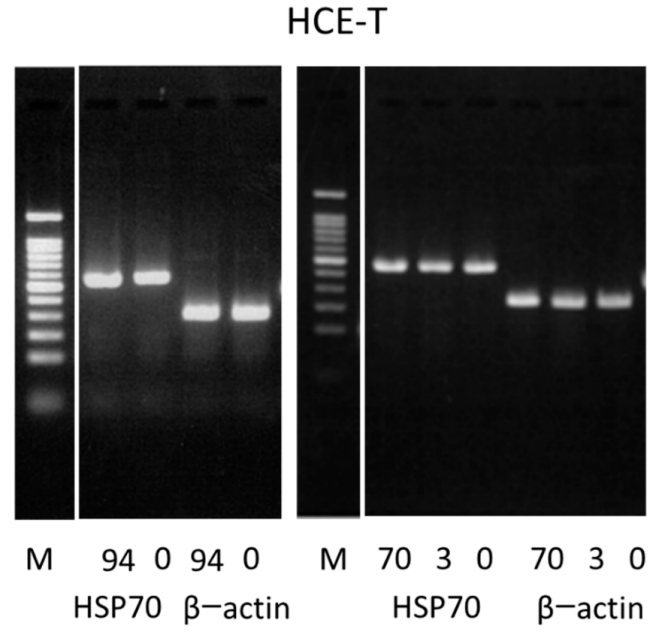

(b)

Figure 9. Level of HSP70 mRNA expression observed by RT-PCR for NB1RGB cell (a) and HCE-T cell (b). Lane M is a DNA molecule size marker. Lane 70 shows cells exposed for $70 \mathrm{~h}$ during cell proliferation, lane 3 shows cells exposed for $3 \mathrm{~h}$ following cell proliferation, and lane 0 shows sham cells. $\beta$-actin was used as an internal standard.

\section{Discussion}

Although the number of studies concerning the biological effect of $\mathrm{THz}$ wave exposure has risen in recent years, the number of completed studies remains small. In particular, there have been few studies conducted to date that have focused on the 0.2-1.0 THz frequency range. The present study was the first to investigate the effect of the exposure to $\mathrm{THz}$ waves at 1-GHz frequency steps within a 0.3-0.6 THz range using a widely tunable source. Frohlich's hypothesis predicts that a possible resonance vibration in the cell membrane will be a non-thermal effect in the THz frequency region [20]. Hadjiloucas et al. previously reported that low power density 200-350 GHz exposure enhanced yeast cell growth due to non-thermal effects [34]. In this study, UTC-PD developed by NTT Corp. for THz light communication, was used as a $\mathrm{THz}$ wave source. The non-thermal effects of $\mathrm{THz}$ waves and/or Frohlich's hypothesis have not yet been proven, and new THz technology may promote concern in the general public as a result. To address this issue, we have undertaken a study of the effect of widely tunable and low power THz waves on human cells, using cultured human skin and corneal cells as recommended in the SCENIHR 2015 report. Cells were subjected to long-term exposure of THz radiation at an intensity sufficiently low to allow assessment of non-thermal effects while disregarding thermal effects.

One prior study that investigated exposure to waves in the $0.3-0.6 \mathrm{THz}$ range involved exposing human skin cells to $0.38 \mathrm{THz}$ waves, with intensities between $0.03-0.9 \mathrm{~mW} / \mathrm{cm}^{2}$, to assess DNA damage. In this study, no measurable effects from exposure to $0.38 \mathrm{THz}$ waves were reported [15].

The occurrence of DNA damage following exposure to $0.1-0.15 \mathrm{THz}$ waves (output power; about $1.5 \mathrm{~kW}$ in $4 \mu \mathrm{s}$ ) has been reported [11]. Titova et al. reported that exposure to $\mathrm{THz}$ pulse at energy of 1.0 and $0.1 \mu \mathrm{J}$ for $10 \mathrm{~min}$ lead to a DNA damage response in human skin tissue model [35]. If DNA had been damaged, subsequent cell growth would also be affected. Although the human skin and 
corneal cells used in the present study were continuously exposed to $\mathrm{THz}$ waves for $94 \mathrm{~h}$, no change in cell growth as a result of exposure to any frequency between 0.3 and $0.6 \mathrm{THz}\left(<1 \mu \mathrm{W} / \mathrm{cm}^{2}\right)$ was observed, and no change in the reactance ratio of unexposed cells was identified (Figure 4). Based on these findings, we report that $\mathrm{THz}$ wave exposure has no effect on cell proliferation. In addition, no changes in cell growth rates were observed under the microscope (Figure 5). No cellular damage or changes to cell proliferation were observed as a result of exposure to $0.3-0.6 \mathrm{THz}$ waves. The exposure power used in these experiments was of very low intensity. Irradiation with high-frequency millimeter or $\mathrm{THz}$ waves can generate heat and damage cells [5]. In this study, as increases in temperature were constrained to under $0.3^{\circ} \mathrm{C}$, thermal effects can be considered to be negligible.

We devised a simple method for irradiating the dishes with $\mathrm{THz}$ waves from above. This allowed us to observe the effects of $\mathrm{THz}$ irradiation using an inverted microscope. This method can be applied to various cells and microbes cultured in dishes. Fluorescence and phase-contrast microscopy showed that neither the cell shape nor the cell membrane changed with irradiation at $0.3,0.4,0.5$, and $0.6 \mathrm{THz}$ waves (Figure 7), whereas they were altered by heating at $43{ }^{\circ} \mathrm{C}$ for $10 \mathrm{~min}$ or the addition of $30 \%$ DMSO (Figure 8). DMSO is generally used as a cryoprotective agent [36], but high concentrations are cytotoxic [37]. The resistance to DMSO differs with cell type and growth stage [38]. The human corneal cells were damaged by heating at $43{ }^{\circ} \mathrm{C}$ for $10 \mathrm{~min}$ or exposure to $30 \%$ DMSO. Therefore, low-intensity, short-duration irradiation did not affect the human corneal cells. There was thought to be no thermal effect, as no morphological changes to the cells were seen.

No effect on the levels of HSP70 mRNA expression following THz wave exposure (Figure 9) was detected. In addition, cell viability of both NB1RGB and HCE-T cells exposed to THz waves for $70 \mathrm{~h}$ during proliferation did not significantly differ compared with the viability of sham cells (Figure 6). No measurable effect on cell viability following $\mathrm{THz}$ exposure was observed, while positive controls exhibited diminished cell proliferation and decreased viability due to changes in temperature $(p<0.01)$. Exposure for $3 \mathrm{~h}$ after cell proliferation is used to test for the cytotoxicity of chemicals and other products: cytotoxicity reduces cell viability $(p<0.01)$. The results of the present study demonstrated that $\mathrm{THz}$ wave exposure did not induce cytotoxic effects and cell viabilities did not change.

Williams et al. [39] reported that the effects of exposure to broadband radiation of up to $\sim 0.5 \mathrm{THz}$ with high peak pulse powers was no difference on cell morphology, adhesion, proliferation, and differentiation between exposure group and control group in HCE-T cells. Although in our study the same cell lines were used, we investigated the non-thermal effects of $0.3-0.6 \mathrm{THz}$ weak continuous wave $(\mathrm{CW})$. And there were no significant changes in the proliferation and metabolic activity of cells exposed to $0.3-0.6 \mathrm{THz} \mathrm{CW}$ radiation compared with unexposed or sham cells, and no morphological changes were observed.

\section{Conclusions}

Novel THz devices are expected to be developed in near future, but few studies have assessed the biological effects of $0.2-2.0 \mathrm{THz}$ radiation. In this report, the exposure to $0.3-0.6 \mathrm{THz}$ waves had no measurable effects on the proliferative or metabolic activities of human skin fibroblasts and corneal epithelial cell lines. No differences in the quantities of cDNA detected were observed between the sham and the exposure group with respect to heat shock protein 70, whose mRNA levels increase in response to heat stress. There were no morphological changes between before and after exposed cells.

Author Contributions: N.Y., H.Y. and S.O. conducted the experiments of cells; S.H. evaluated the exposure conditions; K.K. provided advice regarding the experiments and the paper; and N.Y. wrote the paper.

Funding: This research received no external funding.

Acknowledgments: The authors would like to extend their gratitude to K. Mori, Nagoya University, who assisted with the measurements, and to S. Kato, RIKEN, who assisted with data analysis. This study work was supported by the Ministry of Internal Affairs and Communications (MIC), Japan.

Conflicts of Interest: The authors declare no conflict of interest. 


\section{References}

1. Tonouchi, M. Cutting edge terahertz technology. Nat. Photonics 2007, 1, 97-105. [CrossRef]

2. Song, H.-J.; Ajito, K.; Muramoto, Y.; Wakatsuki, A.; Nagatsuma, T.; Kukutsu, N. 24 Gbit/s data transmission in $300 \mathrm{GHz}$ band for future terahertz communications. Electron. Lett. 2012, 48, 953-954. [CrossRef]

3. Nagatsuma, T. Breakthroughs in photonics 2013; THz communications based on photonics. IEEE Photonics J. 2014, 6, 0701505. [CrossRef]

4. Mattsson, M.-O.; Zeni, O.; Simko, M. Is there a biological basis for therapeutic applications of millimeter waves and THz waves? J. Infrared Millim. Terahertz Waves 2018, 39, 863-878. [CrossRef]

5. Wilmink, G.J.; Grundt, J.E. Invited Review Article: Current state of research on biological effects of terahertz radiation. J. Infrared Millim. Terahertz Waves 2011, 32, 1074-1122. [CrossRef]

6. Scientific Committee on Emerging and Newly Identified Health Risks (SCENIHR). Final Opinion on Potential Health Effects of Exposure to Electromagnetic Fields (EMF) 2015. Available online: https:/ / ec.europa.eu/ health/scientific_committees/emerging/docs/scenihr_o_041.pdf (accessed on 22 March 2019).

7. Korenstein-Ilan, A.; Barbul, A.; Hasin, P.; Eliran, A.; Gover, A.; Korenstein, R. Terahertz radiation increases genomic instability in human lymphocytes. Radiat. Res. 2008, 170, 224-234. [CrossRef]

8. Homenko, A.; Kapilevich, B.; Kornstein, R.; Firer, M.A. Effects of $100 \mathrm{GHz}$ radiation on alkaline phosphatase activity and antigen-antibody interaction. Bioelectromagnetics 2009, 30, 167-175. [CrossRef] [PubMed]

9. Hintzsche, H.; Jastrow, C.; Kleine-Ostmann, T.; Stopper, H.; Schmid, E.; Schrader, T. Terahertz radiation induces spindle disturbances in human-hamster hybrid cells. Radiat. Res. 2011, 175, 569-574. [CrossRef] [PubMed]

10. Hintzsche, H.; Jastrow, C.; Kleine-Ostmann, T.; Kärst, U.; Schrader, T.; Stopper, H. Terahertz electromagnetic fields $(0.106 \mathrm{THz})$ do not induce manifest genomic damage in vitro. PLoS ONE 2012, 7, e46397. [CrossRef]

11. De Amicis, A.; Sanctis, S.D.; Cristofaro, S.D.; Franchini, V.; Lista, F.; Regalbuto, E.; Giovenale, E.; Gallerano, G.P.; Nenzi, P.; Bei, R.; et al. Biological effects of in vitro THz radiation exposure in human foetal fibroblasts. Mutat. Res. Genet. Toxicol. Environ. Mutagen. 2015, 793, 150-160. [CrossRef]

12. Koyama, S.; Narita, E.; Shimizu, Y.; Shiina, T.; Taki, M.; Shinohara, N.; Miyakoshi, J. Twenty Four-Hour Exposure to a $0.12 \mathrm{THz}$ Electromagnetic Field Does Not Affect the Genotoxicity, Morphological Changes, or Expression of Heat Shock Protein in HCE-T Cells. Int. J. Environ. Res. Public Health 2016, 13, 793. [CrossRef]

13. Yaekashiwa, N.; Otsuki, S.; Hayashi, S.; Kawase, K. Investigation on the non-thermal effects of exposing cells to 70-300 GHz using a widely tunable source. J. Radiat. Res. 2018, 59, 116-121. [CrossRef]

14. Alexandrov, B.S.; Rasmussen, K.Ø.; Bishop, A.R.; Usheva, A.; Alexandrov, L.B.; Chong, S.; Dagon, Y.; Booshehri, L.G.; Mielke, C.H.; Phipps, M.L.; et al. Non-thermal effects of terahertz radiation on gene expression in mouse stem cells. Biomed. Opt. Express 2011, 2, 2679-2689. [CrossRef] [PubMed]

15. Hintzsche, H.; Jastrow, C.; Heinen, B.; Baaske, K.; Kleine-Ostmann, T.; Schwerdtfeger, M.; Shakfa, M.K.; Kärst, U.; Koch, M.; Schrader, T.; et al. Terahertz radiation at $0.380 \mathrm{THz}$ and $2.520 \mathrm{THz}$ does not lead to DNA damage in skin cells in vitro. Radiat. Res. 2013, 179, 38-45. [CrossRef]

16. Hwang, Y.; Ahn, J.; Mun, J.; Bae, S.; Jeong, Y.U.; Vinokurov, N.A.; Kim, P. In vivo analysis of THz wave irradiation induced acute inflammatory response in skin by laser-scanning confocal microscopy. Opt. Express 2014, 22, 11465-11475. [CrossRef]

17. Bogomazova, A.N.; Vassina, E.M.; Goryachkovskaya, T.N.; Popik, V.M.; Sokolov, A.S.; Kolchanov, N.A.; Lagarkova, M.A.; Kiselev, S.L.; Peltek, S.E. No DNA damage response and negligible genome-wide transcriptional changes in human embryonic stem cells exposed to terahertz radiation. Sci. Rep. 2015, 5, 7749. [CrossRef]

18. Sergeeva, S.; Demidova, E.; Sinitsyna, O.; Goryachkovskaya, T.; Bryanskaya, A.; Semenov, A.; Meshcheryakova, I.; Dianov, G.; Popik, V.; Peltek, S. 2.3THz radiation: Absence of genotoxicity/mutagenicity in Escherichia coli and Salmonella typhimurium. Mutat. Res. Genet. Toxicol. Environ. Mutagen. 2016, 803-804, 34-38. [CrossRef] [PubMed]

19. Demidova, E.V.; Goryachkovskaya, T.N.; Mescheryakova, I.A.; Malup, T.K.; Semenov, A.I.; Vinokurov, N.A.; Kolchanov, N.A.; Popik, V.M.; Peltek, S.E. Impact of terahertz radiation on stress-sensitive genes of E. coli cell. IEEE Trans. Terahertz Sci. Technol. 2016, 6, 435-441. [CrossRef]

20. Fröhlich, H. Long-range coherence and energy storage in biological systems. Int. J. Quant. Chem. 1968, 2, 641-649. [CrossRef] 
21. Grundler, W.; Keilmann, F.; Fröhlich, H. Resonant growth rate response of yeast cells irradiated by weak microwaves. Phys. Lett. A 1977, 62, 463-466. [CrossRef]

22. Grundler, W.; Keilmann, F. Sharp resonances in yeast growth prove nonthermal sensitivity to microwaves. Phys. Rev. Lett. 1983, 51, 1214-1216. [CrossRef]

23. Jelinek, F.; Saroch, J.; Kucera, O.; Hasek, J.; Pokorny, J.; Jaffrezic-Renault, N.; Ponsonnet, L. Measurement of electromagnetic activity of yeast cells at $42 \mathrm{GHz}$. Radioengineering 2007, 16, 36-39. Available online: http:/ / hdl.handle.net/11012/57274 (accessed on 22 March 2019).

24. Clothier, R.H.; Bourne, N. Effects of THz exposure on human primary kerationocyte differentiation and viability. J. Biol. Phys. 2003, 29, 179-185. [CrossRef] [PubMed]

25. Wilmink, G.J.; Rivest, B.D.; Lbey, B.L.; Roth, C.L.; Bernhard, J.; Roach, W.P. Quantitative investigation of the bioeffects associated with terahertz radiation. Proc. SPIE 2010, 7562, 75620L.

26. Demidova, E.V.; Goryachkovskaya, T.N.; Malup, T.K.; Bannikova, S.V.; Semenov, A.I.; Vinokurov, N.A.; Kolchanov, N.A.; Popik, V.M.; Peltek, S.E. Studying the non-thermal effects of terahertz radiation on E. coli/pKatG-gfp biosensor cells. Bioelectromagnetics 2013, 34, 15-21. [CrossRef] [PubMed]

27. Ito, H.; Nagatsuma, T.; Ishibashi, T. Uni-traveling-carrier photodiodes for high-speed detection and broadband sensing. Proc. SPIE 2007, 6479, 64790X. [CrossRef]

28. Ishibashi, T.; Muramoto, Y.; Yoshimatsu, T.; Ito, H. Continuous THz wave generation by photodiodes up to $2.5 \mathrm{THz}$. In Proceedings of the 38th International Conference Mainz (IRMMW-THz), Mainz, Germany, 1-6 September 2013; pp. 1-2. [CrossRef]

29. Araki-Sasaki, K.; Ohashi, Y.; Sasabe, T.; Hayashi, K.; Watanabe, H.; Tano, Y.; Handa, H. An SV40-immortalized human corneal epithelial cell line and its characterization. Investig. Ophthalmol. Vis. Sci. 1995, 36, 614-621.

30. Mosmann, T. Rapid colorimetric assay for cellular growth and survival: Application to proliferation and cytotoxicity assays. J. Immunol. Methods 1983, 65, 55-63. [CrossRef]

31. Barltrop, J.A.; Owen, T.C.; Cory, A.H.; Cory, J.G. 5-(3-carboxymethoxyphenyl)-2-(4,5-dimethylthiazolyl)-3-(4sulfophenyl)tetrazolium, inner salt (MTS) and related analogs of 3-(4,5-dimethylthiazolyl)-2,5diphenyltetrazolium bromide (MTT) reducing to purple water-soluble formazans as cell-viability indicators. Bioorg. Med. Chem. Lett. 1991, 1, 611-614. [CrossRef]

32. Wang, S.M.; Khandekar, J.D.; Kaul, K.L.; Winchester, D.J.; Morimoto, R.I. A method for the quantitative analysis of human heat shock gene expression using a multiplex RT-PCR assay. Cell Stress Chaperones 1999, 4, 153-161. [CrossRef] [PubMed]

33. Sun, L.; Ke, Y.; Wang, K.; Lu, D.; Hu, H.; Gao, X.; Wang, B.; Zheng, W.; Lou, J.; Wu, W. Effects of 1.8 GHz radiofrequency field on DNA damage and expression of heat shock protein 70 in human lens epithelial cells. Mutat. Res. 2006, 602, 135-142. [CrossRef]

34. Hadjiloucas, S.; Chahal, M.S.; Bowen, J.W. Preliminary results on the non-thermal effects of 200-350 GHz radiation on the growth rate of S. cerevisiae cells in microcolonies. Phys. Med. Biol. 2002, 47, 3831-3839. [CrossRef]

35. Titova, L.V.; Ayesheshim, A.K.; Golubov, A.; Fogen, D.; Rodriguez-Juarez, R.; Hegmann, F.A.; Kovalchuk, O. Intense $\mathrm{THz}$ pulses cause $\mathrm{H} 2 \mathrm{AX}$ phosphorylation and activate DNA damage response in human skin tissue. Biomed. Opt. Express 2013, 4, 559-568. [CrossRef] [PubMed]

36. Rall, W.F.; Fahy, G.M. Ice-free cryopreservation of mouse embryos at -196 degrees C by vitrification. Nature 1985, 313, 573-575. [CrossRef] [PubMed]

37. Hempling, H.G. Mass transfer of liquids across biological barriers. In NATO ASI Series A: The Biophysics of Organ Cryopreservation; Springer: Berlin/Heidelberg, Germany, 1987; Volume 147, pp. 51-78.

38. Suzuki, T.; Komada, H.; Takai, R.; Arii, K.; Kosima, T.T. Relation between toxicity of cryoprotectant DMSO and its concentration in several fish embryo. Fish. Sci. 1995, 61, 193-197. [CrossRef]

39. Williams, R.; Schofield, A.; Holder, G.; Downes, J.; Edgar, D.; Harrison, P.; Siggel-King, M.; Surman, M.; Dunning, D.; Hill, S.; et al. The influence of high intensity terahertz radiation on mammalian cell adhesion, proliferation and differentiation. Phys. Med. Biol. 2013, 58, 373-391. [CrossRef] [PubMed]

(C) 2019 by the authors. Licensee MDPI, Basel, Switzerland. This article is an open access article distributed under the terms and conditions of the Creative Commons Attribution (CC BY) license (http:/ / creativecommons.org/licenses/by/4.0/). 